\title{
Exercise and Oxidative Damage in Nucleoid DNA Quantified Using Single Cell Gel Electrophoresis: Present and Future Application
}

\author{
Gareth W. Davison * \\ Sport and Exercise Science Research Institute, Ulster University, Belfast, UK
}

High intensity exercise can enhance the production of reactive oxygen and nitrogen free radical species, which may cause a number of perturbations to cellular integrity, including deoxyribonucleic acid (DNA) modification. In the absence of adequate DNA repair, it is theoretically possible that several biological disorders may ensue, in addition to premature aging. This striking hypothesis and supposition can only be realized in the presence of sound methodology for the quantification of DNA damage and repair. The alkaline single-cell gel electrophoresis or "comet assay" is a simple and reliable method for measuring the components of DNA stability in eukaryotic cells. The assay is commonly used in research associated with genotoxicology and in human

OPEN ACCESS

Edited by:

Sruti Shiva,

University of Pittsburgh, USA

Reviewed by:

Brett Anthony Kaufman, University of Plttsburgh, USA

Shobhan Gaddameedhi,

Washington State University, USA

*Correspondence:

Gareth W. Davison

gw.davison@ulster.ac.uk

Specialty section:

This article was submitted to

Oxidant Physiology,

a section of the journal

Frontiers in Physiology

Received: 10 March 2016 Accepted: 08 June 2016

Published: 22 June 2016

Citation:

Davison GW (2016) Exercise and Oxidative Damage in Nucleoid DNA

Quantified Using Single Cell Gel

Electrophoresis: Present and Future Application. Front. Physiol. 7:249.

doi: 10.3389/fphys.2016.00249 bio-monitoring studies concerned with gene-environment interactions; but is currently less appreciated and under-utilized in the domain of exercise science. No exercise related study for example, has incorporated the comet assay combined with fluorescent in situ hybridization methodology to detect and investigate whole genome, telomeric DNA, or gene region-specific DNA damage and repair in cells. Our laboratory and others have used the comet assay in conjunction with lesion-specific endonucleases to measure DNA strand breaks and oxidized bases to confirm that high intensity exercise can damage and destabilize DNA. Thus, the primary function of this review is to highlight recent advances and innovation with the comet assay, in order to enhance our future understanding of the complex interrelationship between exercise and DNA modification in eukaryotic cells. A brief synopsis of the current literature addressing DNA stability as a function of continuous aerobic exercise is also included.

Keywords: DNA strand breaks, DNA repair, comet assay, single cell gel electrophoresis, exercise-induced oxidative stress, free radical damage, antioxidant

\section{INTRODUCTION}

\section{Exercise, Free Radical Production and DNA Damage}

It is well accepted that exercise training is associated with a plethora of health benefits, such as a decrease in susceptibility to cancer, diabetes and cardiovascular disease (Warburton et al., 2006). Although regular exercise at a moderate intensity can activate important cell adaptive properties (Ristow et al., 2009), sporadic and strenuous bouts of exercise may induce oxidative stress due to an augmented production of reactive metabolites of oxygen (ROS) and nitrogen free radical species (RNS) (Packer et al., 2008). Exercise-induced free radical formation may impair cell function 
by oxidatively modifying nucleic acids, where DNA damage and insufficient repair may lead to genomic instability and a state of mutagenesis.

While the various mechanistic sources of free radicals attributable to DNA damage following exercise are not well understood, it is certain that the hydroxyl radical $\left({ }^{\bullet} \mathrm{OH}\right)$ plays an integral role. ${ }^{\circ} \mathrm{OH}$ radicals are typically produced in cells by Fenton reactions that involve the reduction of $\mathrm{H}_{2} \mathrm{O}_{2}$ by either ferrous $\left(k \sim 76 \mathrm{M}^{-1} \mathrm{~s}^{-1}\right)$ or copper ions $(k \sim 4.7 \times$ $10^{3} \mathrm{M}^{-1} \mathrm{~s}^{-1}$ ) (Cadet et al., 2012; Halliwell and Gutteridge, 2015). ${ }^{\bullet} \mathrm{OH}$-mediated DNA damage is initiated by electron or hydrogen abstraction or by ${ }^{\bullet} \mathrm{OH}$ reacting with a DNA base and the ribose sugar backbone at diffusion controlled rates (e.g., 2deoxyguanosine: $5 \times 10^{9} \mathrm{M}^{-1} \mathrm{~s}^{-1}$; Chatgilialoglu et al., 2011). It is estimated that $70 \%$ of ${ }^{\bullet} \mathrm{OH}$ reacts with DNA bases, and $30 \%$ with deoxyribose moieties (Nikitaki et al., 2015). As Cobley et al. (2015) points out, the chemistry of ${ }^{\bullet} \mathrm{OH}$-mediated DNA is inherently complex, and may be explained using a propagation type approach. It is currently understood that when ${ }^{\bullet} \mathrm{OH}$ attaches to a DNA base, DNA-centered radicals are produced. These radicals can subsequently react with oxygen $\left(\mathrm{O}_{2}\right)$ or other free radical species such as superoxide $\left(\mathrm{O}_{2}^{\bullet-}\right)$ or nitric oxide (NO), to form a DNA oxidized end product (Ramirez et al., 2007). Accordingly, with the addition of $\bullet \mathrm{OH}$ onto a DNA base aromatic ring, there can be as many as 70 different oxidation end-products produced (Nikitaki et al., 2015).

A number of assays have been developed over the years to quantify DNA free radicals directly (electron paramagnetic resonance spectroscopy and/or immuno-spin trapping), as well as the by-products of DNA damage and oxidation. With regard to the latter, one particular method that has been utilized, but not extensively, to quantify DNA damage following exercise is the single cell gel electrophoresis assay, otherwise known as the comet assay (Figure 1). The purpose of this review and indeed its novel feature, is to ascertain the use of the comet assay in human exercise studies, and to highlight recent advances associated with the assay. The final section will determine how this innovation can enhance our future understanding of the complex interrelationship between exercise and DNA modification.

\section{Comet Assay Background}

The comet assay (alkaline single-cell gel electrophoresis) is regarded as a simple and sensitive method for measuring single and double-stranded DNA breaks in peripheral mononuclear cells (Azqueta and Collins, 2013). The concept of using electrophoresis as a method to determine DNA single strand breaks following relaxation of DNA supercoils was first devised by Ostling and Johanson in 1984 (Olive and Banáth, 2006). A few years later, a modified version using alkaline conditions was published by Singh et al. (1988), and as outlined by Olive and Banáth (2006), the assay became attractive to users due to (a) the fact that only 1000 cells were required, (b) the cells did not require tagging with a radio isotope, thus permitting the quantification of damage in any nucleated cell, and lastly (c) the method could prove useful in measuring variations in response to DNA damaging agents within the same or similar populations. In a later experiment using single cells, Olive et al. (1990) modified the original version of Ostling and Johanson's (1984) method, and demonstrated "comet like" images where the comet head contained high-molecular-weight DNA, whilst the comet tail showed the migrating fragments.

The principle of the comet assay involves embedding cells on agarose gel, which are lysed with detergent and a high concentrated salt solution in order to remove membranes, cytoplasm and most of the nuclear material aside from DNA. Even though histone proteins are eliminated, the winding of the DNA remains as a compact structure in the form of supercoiled loops attached to the nuclear matrix, and is referred to as a nucleoid. If supercoiling is relaxed by the presence of a single or double strand break, the loop of the DNA is free to migrate toward the anode when electrophoresis is applied, thus forming a comet tail. The appearance of this comet tail only forms when DNA loops have relaxed supercoiling by virtue of a break (Collins, 2015). Fluorescence microscopy is normally used to quantify the relative intensity of the comet tail which is directly proportional to the frequency of DNA strand breaks (Collins and Azqueta, 2012). Collins and Azqueta (2012) further postulate that the comet assay has the ability to resolve damage up to $\sim 3$ breaks per $10^{9} \mathrm{Da}$, while at a higher degree of damage, essentially all DNA loops are in a relaxed state and located within the tail.

\section{COMET ASSAY APPLICATION}

\section{Lesion-Specific Endonucleases}

Oxidation of bases in DNA can occur at a similar rate to DNA strand breaks (Collins et al., 2008). A modified version of the standard alkaline comet assay may be used to examine oxidized DNA bases, by detecting oxidized purines (guanine and adenine) and pyrimidines (thymine and cytosine) using lesion-specific enzymes. The modification involves an additional step to the standard assay, where following lysis of agarose-embedded cells, the nucleoid is digested with a lesion-specific endonuclease, such as formamidopyrimidine DNA glycosylase (FPG) for oxidized purine detection (principally 8-oxoguanine), or endonuclease III for evidence of pyrimidine oxidation. This process of enzyme digestion is designed to recognize a specific type of damage in the DNA and create a break (Collins, 2004). Base oxidation is ultimately determined by subtracting the score from a control incubation with buffer (DNA strand breaks) from the score with enzyme incubation, to give the score for "net enzyme-sensitive site damage" (Collins et al., 2008).

\section{Comet-FISH}

The comet assay can be combined with fluorescent in situ hybridization (FISH) methodology to detect and investigate whole genome, telomeric DNA, centrometric DNA and gene region-specific DNA damage and repair in cells. Whereas the standard comet assay allows for the separating of fragmented from non-fragmented DNA, comet-FISH uses a hybridization step following electrophoresis, which permits the detection of labeled DNA sequences by using probes of cDNA or oligonucleotides (Collins, 2004; Glei et al., 2009). This technique allows for assignment of the probed sequences to the damaged (tail DNA) or undamaged (head DNA) part of the comet. When 


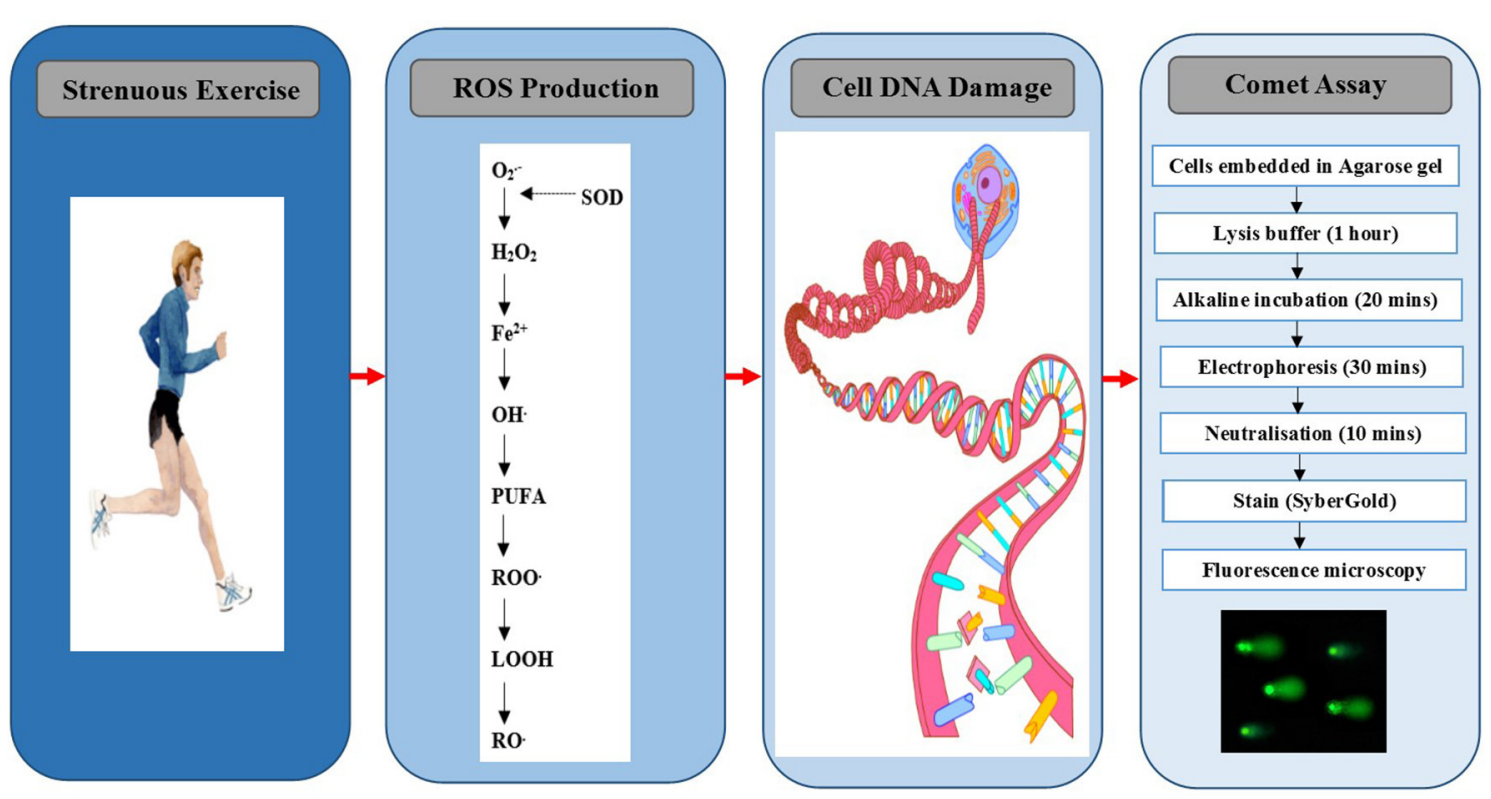

FIGURE 1 | Exercise-induced nucleoid DNA damage quantified by the comet assay. $\mathrm{O}_{2}^{-}$, superoxide; SOD, superoxide dismutase; $\mathrm{H}_{2} \mathrm{O}_{2}$, hydrogen peroxide, $\mathrm{Fe}^{2+}$, iron; $\mathrm{OH}$, hydroxyl; PUFA, polyunsaturated fatty acid; ROO, peroxyl; $\mathrm{LOOH}$, lipid hydroperoxide; RO, alkoxyl.

two fluorescence signals are detected with a probe for a particular gene in the head of a comet, this highlights that the gene is in the vicinity of intact and undamaged DNA in the nuclear matrix, whilst the appearance of a spot(s) in the tail of a comet suggests that DNA damage has occurred close to the site of the probed gene (Glei et al., 2009). It is therefore pertinent to highlight that the comet-FISH assay detects DNA damage and repair only within the vicinity of a probed gene, as oppose to quantifying actual gene modification. To date, the use of the comet-FISH assay has largely been confided to the study of DNA damage and repair within cells associated with cancer (McKelvey-Martin et al., 1998; McKenna et al., 2003), gene fragmentation resulting from x-ray irradiation (Amendola et al., 2006) and in studies interested in telomere behavior (Arutyunyan et al., 2004).

\section{Measuring DNA Repair}

Human cells contain a plethora of repair enzymes that have the ability to positively modify and correct DNA damage prior to it causing severe genomic instability. Indeed, cells have various DNA repair pathways, involving multiple enzymes that deal with a distinct type of damage. For example, where free radicals generated by metabolism are the prime culprits at initiating DNA damage, the base excision repair (BER) pathway is primarily associated with small base alterations (Azqueta et al., 2014).

The cellular repair assay or "challenge" assay, is regarded as one of the most simplistic and functional methods for quantifying DNA repair (Au et al., 2010), and it works on the premise of treating cells with a specific DNA-damaging agent such as $\mathrm{H}_{2} \mathrm{O}_{2}$, and subsequently monitoring the removal of the residual damage over time (Collins and Azqueta, 2014). Whilst the primary purpose of this assay is to monitor strand break rejoining, excision repair of oxidized bases can also be assessed by incorporating the digestion of DNA (nucleoids) with a lesionspecific enzyme such as formamidopyrimidine DNA glycosylase (FPG). This approach can ascertain the removal of DNA lesions, and more specifically the conversion of oxidized purines into strand breaks (Azqueta et al., 2011). As outlined by Shaposhnikov et al. (2011), it is possible to study the DNA repair of specific genes or DNA sequences by modifying the challenge assay to incorporate the basic tenets of the comet assay with fluorescent in situ hybridization (FISH).

An alternative assay at measuring DNA repair, is the cometbased in vitro repair assay by Collins et al. (2001), and this approach is favored for monitoring the response of lymphocytes to low levels of DNA damage. This particular assay works in converse to the cellular repair assay, where DNA nucleoids containing a specific lesion are incubated with a cell extract containing a certain amount of repair enzyme (Collins et al., 2001).

\section{Recent Comet Assay Innovation and Modifications}

Since the original comet assay, devised by Ostling and Johanson (1984), there have been a multitude of developments and modifications, all designed to make the assay more versatile, innovative and user-friendly. Whilst not comprehensive in approach, a brief overview of the modifications closely aligned to blood collection, handling and processing are provided. Indeed, the following developments can be beneficial to exercise physiologists conducting research in a remote environment and when multiple sample analysis is required. 


\section{Freezing Whole Blood}

Preservation of cells for DNA damage quantification using the comet assay, conventionally involves the isolation of lymphocytes by centrifugation, suspension in freezing medium and slow freezing to $-80^{\circ} \mathrm{C}$. This methodology can be time consuming and laborious. Al-Salmani et al. (2011) showed that small volumes $(\sim 250 \mu \mathrm{l})$ of whole blood can be successfully stored at $-80^{\circ} \mathrm{C}$ for up to 1 month without the use of a cryopreservative, and with no artifactual formation of DNA damage. This approach can also extend to the enzyme-modified comet assay. In a recent follow up study, Akor-Dewu et al. (2014) observed higher basal DNA damage in isolated leucocytes compared with whole blood stored for up to 11 months, however, FPG-sensitive sites were detected more efficiently. This modified method of sample handling can be most applicable when sample number is excessive, and volume is limited, or when blood samples are collected at sites remote from the laboratory (Akor-Dewu et al., 2014).

\section{High Throughput Sample Processing}

A plethora of new initiatives associated with rapid comet assay analysis have been developed over the last number of years, and these include:

(1) More samples on a glass surface; According to Brunborg et al. (2014) the first comet assay commercial kit was available in 1999, where gel samples were separated by hydrophobic spacers. Since then, technology has allowed for a larger glass slide holding 96 samples; however, these large slides can add considerable costs to the assay. As a replacement to the traditional glass slide, a GelBond ${ }^{\circledR}$ polyester film can be used to support agarose gels in a 96-well format (Gutzkow et al., 2013). This innovation is relatively inexpensive and an effective method of processing multiple samples.

(2) Comet scoring; Semi-automated scoring of comets can be extremely time consuming, particularly when it involves 96spot scoring with up to 50 comets per sample (Brunborg et al., 2014). There are at least two automated comet scoring systems available (Imstar Pathfinder ${ }^{\mathrm{TM}}$ and MetaSystems CometImager), which require minimal operator interaction, and are superior in speed and tend to avoid operatordependent bias compared to the semi-automated approach.

\section{EXERCISE AND COMET ASSAY APPLICATION}

In a seminal investigation, Hartmann et al. (1994) demonstrated that exhaustive exercise on a treadmill was sufficient to induce DNA strand breaks $24 \mathrm{~h}$ post-exercise. Consistent with this, others have confirmed that either exhaustive running (Niess et al., 1996; Davison et al., 2005; Fogarty et al., 2013a) or cycling (Mars et al., 1998; Zhang et al., 2004) at or near $V \mathrm{O}_{2 \max }$, or indeed rowing (Sardas et al., 2012) can damage DNA strands immediately or $24 \mathrm{~h}$ following exercise; even though in a few cases trained subjects were used. Using a slightly reduced exercise intensity, Fogarty et al. (2011) demonstrate that cycling at 70\% of oxygen capacity can cause DNA strand breaks, and in a follow up study, continuous maximal leg muscle contractions is also shown to induce DNA damage (Fogarty et al., 2013b). Using a similar exercise model, Gray et al. (2014) observed an increase in DNA damage following repetitive eccentric knee contractions, however, $\mathrm{H}_{2} \mathrm{O}_{2}$ stimulated DNA damage was lower immediately following exercise when fish oils were ingested. In an interesting study at altitude, Møller et al. (2001) observed an increase in DNA strand breaks at rest (compared with sea level) and following acute exercise (compared with pre-exercise). When the length of time or distance associated with exercise is increased, the majority of studies show enhanced DNA strand break damage. For example, single exercise bouts performed over $21.1 \mathrm{~km}$ (Niess et al., 1998), $42 \mathrm{~km}$ (Tsai et al., 2001), and $50 \mathrm{~km}$ (Mastaloudis et al., 2004), or over a fixed amount of time $(2.5 \mathrm{~h}$, Peters et al., 2006) all present an adverse effect on DNA stability either during or following exercise, irrespective of the mode. Consecutive bouts of endurance type exercise on DNA stand breaks have been investigated with mixed outcomes. Using a competitive short triathlon event, Hartmann et al. (1998) observed an increase in DNA migration up to 5 days post-exercise, while Wagner et al. (2010) showed a decrease in DNA migration following ultraendurance exercise. Contrary to this, Briviba et al. (2005) observed no change in DNA strand breaks following two consecutive bouts of endurance exercise (Table 1). Palazzetti et al. (2003) examined exercise training on DNA stability and demonstrated that DNA strand breaks can increase following overload training. It thus appears that acute high intensity, and more prolonged endurance bouts of exercise or exercise training can damage DNA, and this seems to be consistent across trained and untrained individuals or indeed if the exercise occurs in a state of either normoxia or hypoxia.

Relatively few of the above studies have examined DNA lesions in the form of oxidized purines and pyrimidines. Using the comet assay, Hartmann et al. (1998) and Briviba et al. (2005) observed no change in FPG-sensitive sites; however, the latter study did detect a rise in ENDO III-sensitive sites following endurance exercise. This finding is supported by Wagner et al. (2010), and further by Tsai et al. (2001) who documented a change in both FPG and ENDO III-sensitive sites following continuous exercise. With regard to short duration exercise, Tanimura et al quantified DNA damage using the comet assay combined with hOGG1 following a single (2008) and consecutive (2010) bouts of high intensity exercise, and on both occasions DNA base damage increased. Even though DNA strand breakage occurs in hypoxia, there is no evidence that this translates into DNA base oxidation, as FPG and ENDO III do not change as a function of exercise (Møller et al., 2001).

\section{CONCLUSIONS AND FUTURE APPLICATION OF THE COMET ASSAY IN EXERCISE BIOCHEMISTRY}

It is clear from a review of the available literature that highintensity exercise can damage DNA, which is quantified in human cells using the comet assay. However, what is not so clear is whether exercise-induced DNA damage is physiologically 
TABLE 1 | Literature highlighting exercise and DNA damage using the comet assay.

\begin{tabular}{|c|c|c|c|c|}
\hline References & Exercise protocol & Blood type & Parameter & Effect \\
\hline Hartmann et al., 1994 & Run to exhaustion & Leukocytes & SB'S & 个 24 h post-run \\
\hline Niess et al., 1996 & Run to exhaustion & Leukocytes & SB'S & $\mathbf{4} 24 \mathrm{~h}$ post-run \\
\hline Niess et al., 1998 & $21.1 \mathrm{~km}$ run & Leukocytes & SB'S & $\mathbf{4} 24$ h post-run \\
\hline Hartmann et al., 1998 & $1.5 \mathrm{~km}$ swim, $40 \mathrm{~km}$ cycle, $10 \mathrm{~km}$ run & Leukocytes & SB's, FPG-s s & $\begin{array}{l}\text { † SB's } 24 \text { h until } 5 \text { days following exercise; } \\
\leftrightarrow \text { FPG-s s }\end{array}$ \\
\hline Mars et al., 1998 & Run to exhaustion & Lymphocytes & SB'S & $\mathbf{4} 24$ h post-run \\
\hline Møller et al., 2001 & $\begin{array}{l}\text { Exhaustive bike test in normoxia and } \\
\text { hypoxia }\end{array}$ & Lymphocytes & SB's, FPG-s s, ENDO III-s s & $\begin{array}{l}\text { † SB's immediately following exercise in } \\
\text { hypoxia; } \leftrightarrow \text { FPG-s s and ENDO III-s s } \\
\text { after exercise in normoxia and hypoxia }\end{array}$ \\
\hline Tsai et al., 2001 & 42 km run & PBMC & SB's, FPG-s s, ENDO-III-s s & $\begin{array}{l}\text { SB's } \uparrow 24 \text { h post-run, FPG, and } \\
\text { ENDO-III-s s } \uparrow \text { immediately post-run }\end{array}$ \\
\hline Palazzetti et al., 2003 & 4 weeks of overload exercise & Leukocytes & SB'S & † Immediately after overload exercise \\
\hline Zhang et al., 2004 & Exhaustion bike test & Leukocytes & SB's & 个 $6 \mathrm{~h}$ and $24 \mathrm{~h}$ post-exercise \\
\hline Mastaloudis et al., 2004 & 50 km ultra-run & Leukocytes & SB'S & SB's $\boldsymbol{\uparrow}$ at half distance \\
\hline Briviba et al., 2005 & $21.1 \mathrm{~km}$ and $41.2 \mathrm{~km}$ runs & Lymphocytes & SB's, FPG-s s, ENDO III-s s & $\begin{array}{l}\text { ENDO-III-s s } \uparrow \text { following both runs, SB's } \\
\text { and FPG } \leftrightarrow \text { immediately after both runs }\end{array}$ \\
\hline Davison et al., 2005 & Run to exhaustion & PBMC & SB'S & 4 Following exercise \\
\hline Peters et al., 2006 & $2.5 \mathrm{~h}$ run at $75 \% \mathrm{VO}_{2 \max }$ & Lymphocytes & SB'S & $\leftrightarrow$ Immediately after and $3 \mathrm{~h}$ post-run \\
\hline Tanimura et al., 2008 & $1 \mathrm{~h}$ cycling at $75 \% \mathrm{VO}_{2 \max }$ & Lymphocytes & SB's with hOGG1 & 个 3 h post-exercise \\
\hline Reichhold et al., 2009 & 3.8 km swim, 180 km cycle, 42 km run & Lymphocytes & SB'S & † 24 h post-exercise \\
\hline Tanimura et al., 2010 & $3 \times 1$ h cycling at $75 \% V^{2} O_{2 x}$ & Lymphocytes & SB's with hOGG1 & † Over consecutive sessions \\
\hline Wagner et al., 2010 & 3.8 km swim, 180 km cycle, 42 km run & Lymphocytes & SB's, FPG-s s, ENDO III-s s & $\begin{array}{l}\text { SB's } \downarrow \text { immediately post-exercise. ENDO } \\
\text { III-s s } \uparrow 5 \text { day post-exercise. }\end{array}$ \\
\hline Fogarty et al., 2011 & Bike test at 40,70 , and $100 \% V^{2 \max }$ & Leukocytes & SB's & 个 At 70 and $100 \% V_{2} O_{\max }$ \\
\hline Sardas et al., 2012 & $2000 \mathrm{M}$ rowing at $80 \%$ peak power & Lymphocytes & SB'S & 424 h post-exercise \\
\hline Fogarty et al., 2013a & Run to exhaustion & Lymphocytes & SB's & † Following exercise \\
\hline Fogarty et al., 2013b & $\begin{array}{l}100 \text { isolated and maximal knee } \\
\text { extension contractions }\end{array}$ & Lymphocytes & SB's & A Following muscle contractions \\
\hline Gray et al., 2014 & $\begin{array}{l}200 \text { eccentric knee contractions with } \\
\text { and without fish oil ingestion }\end{array}$ & Lymphocytes & $\begin{array}{l}\text { SB's, } \mathrm{H}_{2} \mathrm{O}_{2} \text { stimulated } \\
\text { damage }\end{array}$ & $\begin{array}{l}\text { † Immediately following muscle } \\
\text { contractions (pooled group data); } \downarrow \\
\text { following exercise with fish oil ingestion }\end{array}$ \\
\hline
\end{tabular}

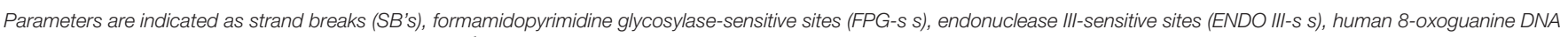
glycosylase (hOGG1). Effects indicated as $\boldsymbol{\uparrow}$ increase; $\downarrow$ decrease; $\leftrightarrow$ no change. Peripheral blood mononuclear cells (PBMC); Maximal oxygen uptake (VO2 max).

important in that it may be counterproductive to human health, particularly when one considers that excessive damage to DNA is associated with human pathology. Whilst not related to exercise per se, Halliwell and Gutteridge (2015) eloquently articulates the consequences of damage to DNA by reactive species. DNA damage can inhibit DNA replication and cell division, and an excessive amount of damage can cause cell death via p53mediated apoptosis and/or $\mathrm{NAD}^{+}$depletion. The p53 gene in particular is an important tumor suppressor gene and a transcription factor protein that can detect DNA instability, and when it does, it puts the break on the cell cycle process and initiates DNA repair. Although the p53 gene is often referred to as "the guardian of the genome," it is also the most frequently mutated gene in human cancers (Halliwell and Gutteridge, 2015). Whilst high-intensity exercise has the potential to cause DNA damage, we know little regarding the effects of p53 stability and its potential to be adversely disturbed following exercise. The comet assay along with fluorescent in situ hybridization can detect and investigate gene region-specific DNA damage in cells.
Although the assay does not determine actual gene modification, but alternatively the DNA damage and repair within the vicinity of a probed gene, the assay can act as a first step to enhance our understanding of the interrelationship between exercise, DNA damage and possible gene disruption.

Complete repair of DNA damage is required for cell survival without excessive mutation (Halliwell and Gutteridge, 2015). Base excision repair removes damage within a base, by using DNA glycosylase enzymes to hydrolyse the bond linking the damaged base to the sugar-phosphate backbone. An example of a glycosylase enzyme in humans is OGG1 which removes $8 \mathrm{OHG}$, leaving a apurinic or apyrimidinic mutagenic site in DNA. It is generally accepted that one of the best ways to characterize DNA stability in vivo, is to contextualize "steadystate" damage, which is essentially the balance between damage and repair. Hence, a rise in cellular DNA damage could be due to increased damage, decreased repair, or both (Halliwell and Gutteridge, 2015). In stating this salient point, the majority of studies concerning exercise and DNA stability, have not taken the 
approach of measuring DNA damage and repair simultaneously. The need to incorporate this step-change into future exercise and DNA stability studies is further accentuated by the necessity to accurately interpret data outcomes; which is augmented by using the same assay approach. To this authors knowledge, no study has exploited the comet assay to address the notion of exercise and DNA (in)stability from a steady state perspective (i.e., measuring both DNA and repair in tandem). The aforementioned approach may be achieved by using the basic comet assay (strand breaks) alongside a requisite modification to incorporate the in vitro repair assay.

\section{CONCLUDING PERSPECTIVES}

The comet assay is a simple and reliable method for quantifying DNA stability in eukaryotic cells, but is under-utilized and less appreciated in studies relating to exercise science. In fact, the assay has only been utilized in blood lymphocyte cells, whilst there is a need to examine different cell types such as muscle, in order to fully appreciate the effects of exercise on DNA modification and redox biology. The domain of exerciseinduced DNA damage is inherently complex, and it is clear

\section{REFERENCES}

Azqueta, A., and Collins, A. R. (2013). The essential comet assay: a comprehensive guide to measuring DNA damage and repair. Arch. Toxicol. 87, 949-968. doi: 10.1007/s00204-013-1070-0

Akor-Dewu, M. B., El Yamani, N., Bilyk, O., Holtung, L., Tjelle, T. E., Blomhoff, R., et al. (2014). Leucocytes isolated from simply frozen whole blood can be used in human biomonitoring for DNA damage measurement with the comet assay. Cell Biochem. Funct. 32, 299-302. doi: 10.1002/cbf.3016

Al-Salmani, K., Abbas, H. H., Schulpen, S., Karbaschi, M., Abdalla, I., Bowman, K. J., et al. (2011). Simplified method for the collection, storage, and comet assay analysis of DNA damage in whole blood. Free Radic. Biol. Med. 51, 719-725. doi: 10.1016/j.freeradbiomed.2011.05.020

Amendola, R., Basso, E., Pacifici, P. G., Piras, E., Giovanetti, A., Volpato, C., et al. (2006). Ret, Abl1 (cAbl) and Trp53 gene fragmentations in comet-FISH assay act as in vivo biomarkers of radiation exposure in C57BL/6 and CBA/J mice. Radiat. Res. 165, 553-561. doi: 10.1667/RR3544.1

Arutyunyan, R., Gebhart, E., Hovhannisyan, G., Greulich, K. O., and Rapp, A. (2004). Comet-FISH using peptide nucleic acid probes detects telomeric repeats in DNA damaged by bleomycin and mitomycin $\mathrm{C}$ proportional to general DNA damage. Mutagenesis 19, 403-408. doi: 10.1093/mutage/ geh049

Au, W. W., Giri, A. K., and Ruchirawat, M. (2010). Challenge assay: a functional biomarker for exposure-induced DNA repair deficiency and for risk of cancer. Int. J. Hyg. Environ. Health 213, 32-39. doi: 10.1016/j.ijheh.2009.09.002

Azqueta, A., Shaposhnikov, S., and Collins, A. R. (2011). "DNA repair measured by the comet assay," in DNA Repair, ed I. Kruman (InTech). Available online at: http://www.intechopen.com/books/dna-repair/dna-repairmeasured-by-the-comet-assay

Azqueta, A., Slyskova, J., Langie, S. A., O’Neill Gaivão, I., and Collins, A. (2014). Comet assay to measure DNA repair: approach and applications. Front. Genet. 5:288. doi: 10.3389/fgene.2014.00288

Briviba, K., Watzl, B., Nickel, K., Kulling, S., Bös, K., Haertel, S., et al. (2005). A half-marathon and a marathon run induce oxidative DNA damage, reduce antioxidant capacity to protect DNA against damage and modify immune function in hobby runners. Redox Rep. 10, 325-331. doi: $10.1179 / 135100005 \times 83716$ that considerable work has yet to be accomplished for a full understanding of the specific consequences (if any) of DNA damage. Moreover, as ROS are important signaling molecules, it is conceivable that DNA damage (stress) may also be beneficial for an efficient adaptive cell response. As such, the dialog associated with this review should stimulate further investigation, and future work ought to use the comet assay to combine DNA damage parameters (strand breaks and nucleotide base modification) alongside a DNA repair approach, while much specificity may also be acquired by examining damage in close proximity to a particular gene of interest (Comet-FISH).

\section{AUTHOR CONTRIBUTIONS}

The author confirms being the sole contributor of this work and approved it for publication.

\section{ACKNOWLEDGMENTS}

I am extremely grateful to Professor Andrew Collins (University of Oslo) for his constructive comments and insightful discussion regarding the content of this review.

Brunborg, G., Jackson, P., Shaposhnikov, S., Dahl, H., Azqueta, A., Collins, A. R., et al. (2014). High throughput sample processing and automated scoring. Front. Genet. 28:373. doi: 10.3389/fgene.2014.00373

Cadet, J., Ravanat, J. L., TavernaPorro, M., Menoni, H., and Angelov, D. (2012). Oxidatively generated complex DNA damage: tandem and clustered lesions. Cancer Lett. 327, 5-15. doi: 10.1016/j.canlet.2012.04.005

Chatgilialoglu, C., D’Angelantonio, M., Kciuk, G., and Bobrowski, K. (2011). New insights into the reaction paths of hydroxyl radicals with 2'-deoxyguanosine. Chem. Res. Toxicol. 24, 2200-2206. doi: 10.1021/tx2003245

Cobley, J. N., Margaritelis, N. V., Morton, J. P., Close, G. L., Nikolaidis, M. G., and Malone, J. K. (2015). The basic chemistry of exercise-induced DNA oxidation: oxidative damage, redox signaling, and their interplay. Front. Physiol. 6:182. doi: 10.3389/fphys.2015.00182

Collins, A. R. (2004). The comet assay for DNA damage and repair: principles, applications, and limitations. Mol. Biotechnol. 26, 249-261. doi: 10.1385/MB:26:3:249

Collins, A. R. (2015). The comet assay: a heavenly method! Mutagenesis 30, 1-4. doi: 10.1093/mutage/geu079

Collins, A. R., and Azqueta, A. (2012). DNA repair as a biomarker in human biomonitoring studies; further applications of the comet assay. Mutat. Res. 736, 122-129. doi: 10.1016/j.mrfmmm.2011.03.005

Collins, A. R., and Azqueta, A. (2014). "Methods for measuring DNA repair: introduction and cellular repair," in Genotoxicity and DNA Repair: A Practical Approach, eds S. L. Maria and G. Isabel (New York, NY: Humana Press), 365-376.

Collins, A. R., Dusinská, M., Horváthová, E., Munro, E., Savio, M., and Stĕtina, R. (2001). Inter-individual differences in repair of DNA base oxidation, measured in vitro with the comet assay. Mutagenesis 16, 297-301. doi: 10.1093/mutage/16.4.297

Collins, A. R., Oscoz, A. A., Brunborg, G., Gaivão, I., Giovannelli, L., Kruszewski, M., et al. (2008). The comet assay: topical issues. Mutagenesis 23, 143-151. doi: 10.1093/mutage/gem051

Davison, G. W., Hughes, C. M., and Bell, R. A. (2005). Exercise and mononuclear cell DNA damage: the effects of antioxidant supplementation. Int. J. Sport Nutr. Exerc. Metab. 15, 480-492.

Fogarty, M. C., De Vito, G., Hughes, C. M., Burke, G., Brown, J. C., McEneny, J., et al. (2013b). Effects of $\alpha$-lipoic acid on mtDNA damage after 
isolated muscle contractions. Med. Sci. Sports Exerc. 45, 1469-1477. doi: 10.1249/MSS.0b013e31828bf31e

Fogarty, M. C., Hughes, C. M., Burke, G., Brown, J. C., Trinick, T. R., Duly, E., et al. (2011). Exercise-induced lipid peroxidation: implications for deoxyribonucleic acid damage and systemic free radical generation. Environ. Mol. Mutagen 52, 35-42. doi: 10.1002/em.20572

Fogarty, M. C., Hughes, C. M., Burke, G., and Brown, J. C., and Davison, G.W. (2013a). Acute and chronic watercress supplementation attenuates exerciseinduced peripheral mononuclear cell DNA damage and lipid peroxidation. $\mathrm{Br}$. J. Nutr. 109, 293-301. doi: 10.1017/S0007114512000992

Glei, M., Hovhannisyan, G., and Pool-Zobel, B. L. (2009). Use of Comet-FISH in the study of DNA damage and repair: review. Mutat. Res. 681, 33-43. doi: 10.1016/j.mrrev.2008.01.006

Gray, P., Chappell, A., Jenkinson, A. M., Thies, F., and Gray, S. R. (2014). Fish oil supplementation reduces markers of oxidative stress but not muscle soreness after eccentric exercise. Int. J. Sport Nutr. Exerc. Metab. 24, 206-214. doi: 10.1123/ijsnem.2013-0081

Gutzkow, K. B., Langleite, T. M., Meier, S., Graupner, A., Collins, A. R., and Brunborg, G. (2013). High-throughput comet assay using 96 minigels. Mutagenesis 28, 333-340. doi: 10.1093/mutage/get012

Halliwell, B., and Gutteridge, J. M. C. (2015). Free Radicals in Biology and Medicine, 5th Edn. Oxford: Oxford University Press.

Hartmann, A., Pfuhler, S., Dennog, C., Germadnik, D., Pilger, A., and Speit, G. (1998). Exercise-induced DNA effects in human leukocytes are not accompanied by increased formation of 8-hydroxy-2'-deoxyguanosine or induction of micronuclei. Free Radic. Biol. Med. 24, 245-251. doi: 10.1016/S0891-5849(97)00249-9

Hartmann, A., Plappert, U., Raddatz, K., Grünert-Fuchs, M., and Speit, G. (1994). Does physical activity induce DNA damage? Mutagenesis 9, 269-272. doi: 10.1093/mutage/9.3.269

Mars, M., Govender, S., Weston, A., Naicker, V., and Chuturgoon, A. (1998). High intensity exercise: a cause of lymphocyte apoptosis? Biochem. Biophys. Res. Commun. 249, 366-370. doi: 10.1006/bbrc.1998.9156

Mastaloudis, A., Yu, T. W., O’Donnell, R. P., Frei, B., Dashwood, R. H., and Traber, M. G. (2004). Endurance exercise results in DNA damage as detected by the comet assay. Free Radic. Biol. Med. 36, 966-975. doi: 10.1016/j.freeradbiomed.2004.01.012

McKelvey-Martin, V. J., Ho, E. T., McKeown, S. R., Johnston, S. R., McCarthy, P. J., Rajab, N. F., et al. (1998). Emerging applications of the single cell gel electrophoresis (Comet) assay. I. Management of invasive transitional cell human bladder carcinoma. II. Fluorescent in situ hybridization Comets for the identification of damaged and repaired DNA sequences in individual cells. Mutagenesis 13, 1-8. doi: 10.1093/mutage/13.1.1

McKenna, D. J., Rajab, N. F., McKeown, S. R., McKerr, G., and McKelvey-Martin, V. J. (2003). Use of the comet-FISH assay to demonstrate repair of the TP53 gene region in two human bladder carcinoma cell lines. Radiat. Res. 159, 49-56. doi: 10.1667/0033-7587(2003)159[0049:UOTCFA]2.0.CO;2

Møller, P., Loft, S., Lundby, C., and Olsen, N. V. (2001). Acute hypoxia and hypoxic exercise induce DNA strand breaks and oxidative DNA damage in humans. FASEB J. 15, 1181-1186. doi: 10.1096/fj.00-0703com

Niess, A. M., Baumann, M., Roecker, K., Horstmann, T., Mayer, F., and Dickhuth, H. H. (1998). Effects of intensive endurance exercise on DNA damage in leucocytes. J. Sports Med. Phys. Fitness. 38, 111-115.

Niess, A. M., Hartmann, A., Grünert-Fuchs, M., Poch, B., and Speit, G. (1996). DNA damage after exhaustive treadmill running in trained and untrained men. Int. J. Sports Med. 17, 397-403. doi: 10.1055/s-2007-972868

Nikitaki, Z., Hellweg, C. E., Georgakilas, A. G., and Ravanat, J. L. (2015). Stressinduced DNA damage biomarkers: applications and limitations. Front Chem. 3:35. doi: 10.3389/fchem.2015.00035

Olive, P. L., and Banáth, J. P. (2006). The comet assay: a method to measure DNA damage in individual cells. Nat. Protoc. 1, 23-29. doi: 10.1038/nprot.2006.5

Olive, P. L., Banáth, J. P., and Durand, R. E. (1990). Heterogeneity in radiationinduced DNA damage and repair in tumor and normal cells measured using the "comet" assay. Radiat. Res. 122, 86-94. doi: 10.2307/3577587

Ostling, O., and Johanson, K. J. (1984). Microelectrophoretic study of radiationinduced DNA damages in individual mammalian cells. Biochem. Biophys. Res. Commun. 123, 291-298. doi: 10.1016/0006-291X(84)90411-X
Packer, L., Cadenas, E., and Davies, K. J. (2008). Free radicals and exercise: an introduction. Free Radic. Biol. Med. 44, 123-125. doi: 10.1016/j.freeradbiomed.2007.05.031

Palazzetti, S., Richard, M. J., Favier, A., and Margaritis, I. (2003). Overloaded training increases exercise-induced oxidative stress and damage. Can. J. Appl. Physiol. 28, 588-604. doi: 10.1139/h03-045

Peters, E. M., Van Eden, M., Tyler, N., Ramautar, A., and Chuturgoon, A. A. (2006). Prolonged exercise does not cause lymphocyte DNA damage or increased apoptosis in well-trained endurance athletes. Eur. J. Appl. Physiol. 98, 124-131. doi: 10.1007/s00421-006-0227-4

Ramirez, D. C., Gomez-Mejiba, S. E., and Mason, R. P. (2007). Immunospin trapping analyses of DNA radicals. Nat. Protoc. 2, 512-522. doi: 10.1038/nprot.2007.5

Reichhold, S., Neubauer, O., Hoelzl, C., Stadlmayr, B., Valentini, J., Ferk, F., et al. (2009). DNA damage in response to an ironman triathlon. Free Radic. Res. 43, 753-760. doi: 10.1080/10715760903040628

Ristow, M., Zarse, K., Oberbach, A., Klöting, N., Birringer, M., Kiehntopf, M., et al. (2009). Antioxidants prevent health-promoting effects of physical exercise in humans. Proc. Natl. Acad. Sci. U.S.A. 106, 8665-8670. doi: 10.1073/pnas.0903485106

Sardas, S., Omurtag, G. Z., Monteiro, I. F. C., Beyoglu, D., Tozan-Beceren, A., Topsakal, N., et al. (2012). Assessment of DNA damage and protective role of Vitamin E Supplements after exhaustive exercise by comet assay in athletes. $J$. Clinic. Toxicol. S5:001. doi: 10.4172/2161-0495.S5-001

Shaposhnikov, S., Thomsen, P. D., and Collins, A. R. (2011). Combining fluorescent in situ hybridization with the comet assay for targeted examination of DNA damage and repair. Methods Mol. Biol. 682, 115-132. doi: 10.1007/9781-60327-409-8_10

Singh, N. P., McCoy, M. T., Tice, R. R., and Schneider, E. L. (1988). A simple technique for quantitation of low levels of DNA damage in individual cells. Exp. Cell Res. 175, 184-191. doi: 10.1016/0014-4827(88)90265-0

Tanimura, Y., Shimizu, K., Tanabe, K., Kono, I., and Ajisaka, R. (2010). Effects of three consecutive days exercise on lymphocyte DNA damage in young men. Eur. J. Appl. Physiol. 110, 307-314. doi: 10.1007/s00421-010-1499-2

Tanimura, Y., Shimizu, K., Tanabe, K., Otsuki, T., Yamauchi, R., Matsubara, Y., et al. (2008). Exercise-induced oxidative DNA damage and lymphocytopenia in sedentary young males. Med. Sci. Sports Exerc. 40, 1455-1462. doi: 10.1249/MSS.0b013e31817242cf

Tsai, K., Hsu, T. G., Hsu, K. M., Cheng, H., Liu, T. Y., Hsu, C. F., et al. (2001). Oxidative DNA damage in human peripheral leukocytes induced by massive aerobic exercise. Free Radic. Biol. Med. 31, 1465-1472. doi: 10.1016/S08915849(01)00729-8

Wagner, K. H., Reichhold, S., Hölzl, C., Knasmüller, S., Nics, L., Meisel, M., et al. (2010). Well-trained, healthy triathletes experience no adverse health risks regarding oxidative stress and DNA damage by participating in an ultra-endurance event. Toxicology 278, 211-216. doi: 10.1016/j.tox.2009.09.006

Warburton, D. E., Nicol, C. W., and Bredin, S. S. (2006). Prescribing exercise as preventive therapy. CMAJ 174, 961-974. doi: 10.1503/cmaj.1040750

Zhang, M., Izumi, I., Kagamimori, S., Sokejima, S., Yamagami, T., Liu, Z., et al. (2004). Role of taurine supplementation to prevent exercise-induced oxidative stress in healthy young men. Amino Acids. 26, 203-207. doi: 10.1007/s00726003-0002-3

Conflict of Interest Statement: The author declares that the research was conducted in the absence of any commercial or financial relationships that could be construed as a potential conflict of interest.

The reviewer BK and handling Editor declared their shared affiliation, and the handling Editor states that the process nevertheless met the standards of a fair and objective review.

Copyright $\odot 2016$ Davison. This is an open-access article distributed under the terms of the Creative Commons Attribution License (CC BY). The use, distribution or reproduction in other forums is permitted, provided the original author(s) or licensor are credited and that the original publication in this journal is cited, in accordance with accepted academic practice. No use, distribution or reproduction is permitted which does not comply with these terms. 